\title{
Üniversite Öğrencilerinin Salgın Dönemi Uzaktan Eğitim Deneyimleri: Ordu Üniversitesi Sosyoloji Bölümü ve Besyo Örneği ${ }^{1}$
}

\author{
Distance Learning Experiences of University Students in the Epidemic Period: Ordu \\ University Department of Sociology and PESVS Sample
}

Erol BULUT ${ }^{2}$

\author{
Araştırma Makalesi / Research Article \\ Geliș Tarihi / Received: 26.05.2021 \\ Kabul Tarihi / Accepted: 25.06.2021 \\ Doi: 10.48146/odusobiad.943135
}

Atıf / Citation: Bulut, E.., (2021). "Üniversite Öğrencilerinin Salgın Dönemi Uzaktan Eğitim Deneyimleri: Ordu Üniversitesi Sosyoloji Bölümü ve Besyo Örneği” ODÜSOBIAD 11(2), 533-548, doi: 10.48146/odusobiad.943135

\section{$\ddot{0} \mathbf{z}$}

Bu çalışma Ordu Üniversitesi sosyoloji bölümü ve Beden Eğitimi ve Spor Meslek Yüksek Okulu'nda (BESYO) öğrenim gören 276 öğrenci ile gerçekleştirilen anket sonuçlarına dayanmaktadır. Anket Google Form üzerinden online olarak uygulanmıştır. Anket formu yapılandırılmış ve açı uçlu sorulardan oluşmaktadır. Çalışma öğrencilerin salgın döneminde uygulanan uzaktan eğitime ilișkin düșünce ve tutumlarına yöneliktir. Araştırmaya katılan öğrencilerin yüzde 61'i kadın, yüzde 38,4'ü erkektir. Öğrencilerin yüzde 57,2'si BESYO'da, yüzde 42,8'i sosyoloji bölümünde okumaktadır. Öğrencilerin yüzde 92'si yüz yüze eğitimi tercih etmektedir. Öğrencilerin canlı ders takip sıklığına ilişkin oranları 'hiç ders kaçırmadığını” belirtenler için yüzde 14,9, 'arasıra dersleri kaçırdığını' belirtenler için yüzde 43,8'dir. Ders tekrarı izleme oranı ise yüzde 39,5'dir. Ders takibi büyük oranla cep telefonu ile gerçekleştirilmektedir (yüzde 59,8). Açık uçlu sorulan tercih nedenlerine verilen cevaplarda verimlilik, anlaşılırlık ve odaklanma ön plana çıkmaktadır. Yine açık uçlu sorulan uzaktan eğitimin avantaj ve dezavantajlarına dair verilen cevaplarda avantaj olarak ev rahatlığı, kayıt/tekrar izleme olanağı ve derslerin salgın döneminde devam edebilmesi, dezavantaj olarak internet sorunları, verimsizlik ve dikkat/odaklanma ön plana çıkmaktadır. Öğrencilerin salgın kurallarına büyük oranda uyduğu görülürken, salgının duygusal durumuna olumsuz etki yaptığını söyleyenlerin oranı yüzde 82,6'dır.

Anahtar Kelimeler: Eğitim, Uzaktan Eğitim, Salgın, Covid19, Sosyoloji.

\begin{abstract}
This paper investigated students' views and attitudes towards distance learning during the COVID-19 pandemic. The sample consisted of 276 students (168 women and $108 \mathrm{men}$ ) from the sociology department ( $\mathrm{n=118}$ ) and physical education and sports vocational school (PESVS) ( $n=158)$ of Ordu University. Data were collected using an online survey consisting of structured and open-ended questions. The majority of the participants (92\%) preferred face-to-face learning. Forty-one participants (14.9\%) "never missed classes" while $43.8 \%$ of the participants "sometimes missed classes." Less than half the participants (39.5\%) watched the classes again. More than half the participants (59.8\%) attended classes on their smartphones. When asked the reason for their preference, participants emphasized efficiency, clarity, and focus. For participants, the advantages of distance learning were that they attended classes from the comforts of their homes, watched classes over and over again, and continued education during the pandemic. As for disadvantages, they talked about Internet issues, inefficiency, and concentration problems. Most participants obeyed the pandemic restrictions. The majority of the participants (82.6\%) stated that the pandemic adversely affected their mood.
\end{abstract}

Keywords: Education, Distance learning, Pandemic, Covid19, Sociology

\footnotetext{
1 T.C. Ordu Üniversitesi Rektörlüğü Sosyal ve Beşeri Bilimler Araştırmaları Etik Kurulu, 29.09.2020, 2020-71 sayılı karar. 2 Dr. Öğr. Üyesi, Fen-Edebiyat Fakültesi, Sosyoloji Bölümü, Ordu, E-Posta: e_bulut10@hotmail.com, ORCID ID: ORCID ID: 0000-0001-7154-4193
} 


\section{Giriş}

Uzaktan eğitim salgın döneminde eğitimin devam etmesini sağlamakla birlikte, öğrencileri, öğretmenleri, okul yönetimlerini ve aileleri derinden etkilemiştir. Örneğin eğitimde okullarla birlikte bir nebze etkisi azalan aile tekrar çocukların eğitiminde en önemli etken olmuştur (Bozkurt, 2020a, s. 121). Diğer taraftan yüz yüze eğitimde yardımcı olarak kullanılan teknoloji eğitimin ana unsuru haline gelmiştir. $\mathrm{Bu}$ nedenle öğretmenlerin/hocaların teknolojiye daha fazla uyum sağlaması gerekmiştir. Okul yönetimleri veya eğitim alanındaki yöneticiler ise belirsizlik içerisindeki sürece anında cevap vermekte zaman zaman zorlanmışlardır. Derslerin ve sınavların nasıl düzenleneceği gibi kararlarda gerçekleșen gecikmeler eğitim aktörleri üzerindeki baskıyı arttırmıștır.

Süreçten hiç kuşkusuz en fazla etkilenenler öğrencilerdir. Teknoloji ile barışık ve teknolojiyi yardımcı unsur olarak kullanmada istekli bir nesil olmakla birlikte, tüm derslerin internet ortamında gerçekleștiriliyor olması öğrencileri zorlayabilmektedir. Ayrıca eğitimin dikkat ve odaklanma sorunlarına açık olan bir ortamda (evde) gerçekleşmesi konuları anlamayı güçleştirebilmektedir. Ayrıca sürecin belirsizliği ve geleceğe yönelik kaygılar öğrencilerin derslere olan ilgilerini azaltabilmektedir. Öğrencilerle birlikte öğretmenlerin/hocaların, ailelerin, yöneticilerin salgın ve kısıtlamalar nedeniyle yaşadıkları stres eğitimin kalitesini düşürebilmektedir. Diğer taraftan uzaktan eğitim teknolojiye uyumu ve bireysel araştırma düzeyini arttırma gibi olumlu yönler içermektedir.

Kısaca uzaktan eğitim süreci avantaj ve dezavantajları ile eğitimde hali hazırda tartışılan değişim sürecini daha belirgin hale getirmiştir. Dolayısıyla gelecekteki eğitime hazır olabilmek için salgın dönemi bir firsat olarak değerlendirilebilir. Yapılan/yapılacak çalışmalar uzaktan eğitim konusundaki eksileri ve artıları görmemizi sağlayarak daha iyi bir eğitim sistemi hazırlamamızı sağlayabilir.

Bu kapsamda öğrencilerin uzaktan eğitime yönelik tutum, davranış ve düşüncelerini görmek amacıyla Ordu Üniversitesi sosyoloji bölümü ve BESYO öğrencileri örneğinde bir anket uygulanmıştır. Çalışmada öncelikle uzaktan eğitim süreci ve etkileri ele alınmaktadır. Daha sonra araştırmanın metodolojisi ve anketten elde edilen verilerin sonuçları ortaya konmaktadır. Tartışma başlı̆̆ı altında ise araştırma sonuçları literatürdeki diğer bazı araștırmalar ile karşılaştırılmaktadır.

\section{Salgın Dönemi Uzaktan Eğitim}

Günümüz toplumları bilgi, iletișim ve teknoloji üçlüsü ile șekillenmektedir. Artan iletișim ve teknoloji olanakları bilgiyi küresel bir güce dönüștürmüştür. Bilgisayar ve internet her tür bilgiye kolayca ve hızlı bir şekilde erişim imkânı sağlamıştır. Zaman ve uzam arasındaki ilişkiyi esnekleştiren teknolojik gelişmeler geleneksel okul temelli eğitimde değişimler yaratmıştır. Uzaktan eğitim bu değişimin en önemli örneğidir.

Uzaktan eğitim, öğrenci ve öğretmenlerin yüz yüze gelmedikleri, öğrenim etkinliklerini iletişim teknolojileri vasıtasıyla gerçekleştirdikleri bir eğitim modelidir (Tezcan, 2016, s. 293). Uzaktan eğitim "bireyin kendi kendine öğrenmesini amaçlayan, eğitsel içeriklerin öğrenenlere özel olarak hazırlanmış araçlarla ve çeşitli ortamlar yoluyla sağlandığı bir öğretim yöntemi olarak da tanımlanabilir" (Banar ve Fırat, 2015, s. 19). Uzaktan eğitim geçmişte posta yoluyla/mektupla öğretim şeklinde gerçekleşirken günümüzde internet teknolojisi ile sağlanmaktadır. Bu kapsamda uzaktan eğitim 1700'lü ylllarda mektupla öğretim, 1960'larda uzaktan eğitim üniversitelerinin kurulmasıyla önemli bir dönüşüm yaşamış ve günümüzde internet teknolojileri ile giderek yaygınlaşmıștır. (Özbay, 2015, s. 378) Günümüzde Türkiye dâhil olmak üzere dünyada birçok ülkede uzaktan eğitim uygulanmaktadır. Türkiye'de üniversitelerin yaklaşık yüzde 66'sı tarafından uzaktan eğitim yoluyla verilen zorunlu ortak dersler (Yabancı dil, Türk Dili ve Edebiyatı ve Atatürk İlke ve İnkılap Tarihi) bu uygulamanın ülkemizde en bilinen en iyi örneğidir (Eroğlu ve Kalaycı, 2020, s. 238). Yine Anadolu Üniversitesi, İstanbul Üniversitesi ve Atatürk Üniversitesi açıöğretim fakülteleri uzaktan eğitim uygulamasına örnektir. Çeşitli üniversite, program ve derslerde yapılan uzaktan eğitim COVID 19 salgını ile Türkiye'deki tüm eğitim kurumlarında uygulanmaya başlanmıştır (Bozkurt, 2020a) salgın dönemi uygulanan eğitim modelinin "acil uzaktan eğitim" olarak tanımlanması gerektiğini belirtmektedir).

Aralık 2019'da Çin'de görülen COVID 19 hastalığı, Mart 2020 tarihi itibariyle tüm dünyayı etkisi altına almıştır. Salgın sağlık, ekonomi, siyaset ve toplumsal alanlarda yarattığı etkilerle son yüzyılın en önemli krizlerinden biri olmuştur. Milyonlarca insanın yaşamını yitirmesine, ülke ekonomilerinin 
zayıflamasına, işsizlik ve yoksulluğun yükselmesine, sağlık altyapısındaki eksikleri gün yüzüne çıkartarak modern devletlerin ve uluslararası kuruluşların sorgulanmasına yol açmış ve günlük yaşamımızdaki tüm rutinleri bozmuştur.

Salgından etkilenen en önemli alanlardan biri de eğitimdir. Pandeminin tüm dünyada etkisini göstermesiyle birlikte çoğu ülke eğitime ara vermiş ve uzaktan eğitim sürecine başlamıştır. Türkiye de tüm eğitim kademelerinde eğitime ara vererek, ilköğretim ve lise düzeylerinde EBA sistemi ile uzaktan eğitime devam etmiştir. Üniversitelerde YÖK kararı ile dönemin uzaktan eğitimle tamamlanması kararı alınmıștır. Bu kapsamda Ordu üniversitesi 23 Mart 2020 itibariyle uzaktan eğitim uygulamasına geçmiştir. 2019-2020 bahar döneminde yarım kalan dersler için bazı üniversiteler ders kaynaklarının (ders notu, kitap vb.) internet ortamında paylaşılması ve bu kaynaklar üzerinden sınav yapılması yolunu seçerken, Ordu Üniversitesi hızlı bir şekilde altyapısını hazırlayarak canlı ders uygulamasını devreye sokmuştur. Başta 2019-2020 bahar dönemini kapsayan uzaktan eğitimin, salgının devam etmesi nedeniyle 2020-2021 eğitim öğretim yllının tamamında uygulanması kararlaştıılmıştır. Okulların kapatılması ve uzaktan eğitim süreci eğitimin devam edebilmesi için en iyi çözüm aracı olmakla beraber birçok sorunu beraberinde getirmiştir.

Birleşmiş Milletler raporunda (UN, 2020) pandemi öncesi 250 milyondan fazla çocuğun okula gidemediği ve 387 milyon çocuğun (\%56) temel okuma becerilerinden yoksun olduğu tahmin edilmektedir. Pandemi ise hali hazırdaki bu sorunlara yenilerini eklemiştir. Raporda Nisan 2020'nin ortasına kadar, 200 ülkede ilkokul öncesi eğitimden yükseköğretime kadar 1,58 milyar çocuğun ve gencin (dünya genelindeki öğrencilerin yüzde 94'ü) salgından etkilendiği belirtilmektedir. Okul kapanışlarına cevap verme yeteneği ise, ülkelerin gelişim düzeyine göre çarpıcı bir şekilde değişmektedir. Örneğin, 2020'nin ikinci çeyreğinde, insani gelişmenin düşük olduğu ülkelerde ilköğretimdeki çocukların yüzde 86'sı etkin bir şekilde okula gitmemektedir. Bu oran insani gelişmenin çok yüksek olduğu ülkelerde sadece yüzde 20'dir. COVID-19'un günlük yaşamda neden olduğu kesintiler, dünya çapında 40 milyon çocuğun kritik okul öncesi yıllarında erken çocukluk eğitimini kaçırdı̆̆ı anlamına gelmektedir. En fakir ülkelerin tahmini yüzde 40'ı COVID-19 krizi sırasında risk altındaki öğrencileri destekleyememektedir ve geçmiş deneyimler hem eğitim hem de cinsiyet eşitsizliklerinin salgın dönemlerinde artma eğiliminde olduğunu göstermektedir. Raporda gelir kayıpları ve işsizliğin çocuk işçiliğini artırması ve kız çocuklarının eğitim oranlarını düşürmesi ihtimali dile getirilmektedir. COVID-19 nedeniyle aşırı yoksulluk içindeki insan sayısının 71 ila 100 milyon arasında artacağı tahmin edildiğinden, okul terklerine dikkat edilmesi gerektiği belirtilmektedir. Nispeten az sayıda ülke, uzaktan eğitim yöntemlerinin etkili erişimini ve kullanımını gerçekleștirebilmektedir. Yüksek gelirli ülkelerde uzaktan eğitim yaklaşık yüzde 80-85'i kapsarken, bu oran düşük gelirli ülkelerde yüzde 50'nin altına düşmektedir. Kısaca bilgisayar, internet gibi uzaktan eğitim için gerekli olan araçlara sahip olmak şöyle dursun en temel ihtiyaçlardan elektriğe sahip olmayan öğrencilerin zaten zar zor devam eden eğitimleri bu süreçte tamamen kesilme tehlikesi taşımaktadır.

Benzer şekilde Avrupa komisyonu raporu (Di Pietro et. al 2020) pandemi öncesi okul dışı etkinlikleri ve uzaktan eğitimi kullanan Finlandiya, Danimarka ve İsveç gibi ülkelerle, geleneksel okul eğitimi dışına çıkmamış Romanya, Bulgaristan ve Slovakya gibi ülkelerin arasındaki farkın açılabileceğine değinmektedir. Diğer taraftan raporda ebeveyn mali kaynakları, öğrencilerin dijital becerileri gibi nedenlere bağlı olarak daha az avantajlı geçmișe sahip öğrencilerin, bu acil dönemde, daha fazla öğrenme kaybı yaşayabileceği tahmin edilmektedir. Düşük sosyo-ekonomik konumdaki ebeveynlerin çocukların bilişsel gelişimine katkıları ise daha az olacaktır. Yine uzaktan çalışma imkânına sahip olmayan aileler çocuklarının evde eğitim sürecine çok daha az katkı yapabilecektir. Ayrıca raporda yerli öğrenciler ve göçmen öğrenciler arasında önemli öğrenme eşitsizlikleri ortaya çıkabileceği ifade edilmektedir. Artan eşitsizliğe katkıda bulunabilecek diğer bir etken ise, öğretmenlerin dijital teknolojilere hazırlıklı olmamasında yatmaktadır. Bu kapsamda rapora göre şimdiye kadar daha dezavantajlı çocukları belirlemek için aile geçmişine odaklanılırken, diğer göstergeler gözden kaçırılmamalıdır.

Diğer taraftan, derslerin yapılmasında karşılaşılan internet sorunları, uygulamalı derslerin teorik düzeyde kalması, sınavların yapımında ve değerlendirme sürecindeki belirsizlikler, akademik çalışmaların sekteye uğraması gibi birçok sorun yaşanmaktadır. Salgının sağlık tehdidinin yanı sıra günlük yaşamdaki kısıtlamaların yarattığı stres de bu sorunlara eklenmelidir. Örneğin yapılan araştırmalara göre verimlikteki değişme ile pandemi sonrasında yaşanan stres ve artan kaygı 
arasında yakın bir ilişki bulunmaktadır. Ölüm/mikrop kapma korkusu, geçim derdi arttıkça verimlilik düşmektedir (Bozkurt, 2020b, s. 131). Ailelerdeki bu verimlilik kaybının öğrencileri etkilemediğini söylemek mümkün değildir. Öğrenciler hem ailelerinin ekonomik durumu hem de kendi gelecekleri hakkında kaygılanmaktadırlar. Bu durum öğrencilerin motivasyonunu ciddi derecede etkilemektedir. Pandemi döneminde ve sonrasında artan/artması öngörülen işsizlik yine öğrencilerde motivasyon kaybına neden olabilmektedir. Özellikle son sınıf öğrencileri yoğun bir belirsizlik yaşamaktadır. Ayrıca okul sosyalleşme açısından en önde gelen kurumdur. Dolayısıyla sosyalleşmenin azalması öğrencilerde stresi arttırabilmektedir. Okulda ders dışı etkinliklerin (konferans, kulüp etkinlikleri gibi) ortadan kalkması öğrenme düzeyini ve motivasyonunu düşürmektedir. Yine akademik araştırma faaliyetlerinde kısmi düzeyde aksaklıklar yaşanması eğitimi negatif etkilemektedir.

Kısacası pandemi sonrası, eğitim kurumlarının eğitim sisteminde köklü değişikler yapması söz konusu olabilir. Eğitim kurumları daha fazla teknoloji kullanımına ağırlık verebilir (Karakaş, 2020, s. 566). Ancak teknoloji kullanımı öğrenim kurumlarında arttıkça düşük gelirli ailelerden ve dezavantajlı gruplardan gelen öğrencilerin, yüksek hızlı internet bağlantısını ve çevrimiçi öğrenim için gerekli teknik araçları karşılayamamaları nedeniyle daha geri kalmaları muhtemeldir (Jena, 2020: 80). Dolayısıyla pandemi sonrası eğitimde daha fazla yer alacağı öngörülen teknolojinin eşitsizlikleri azaltııı bir faktör olmasını destekleyen eğitim politikalarının geliştirilmesi elzemdir.

\section{Araştırmanın Metodolojisi}

Araştırmanın konusu Covid 19 salgını döneminde Ordu Üniversitesi Sosyoloji Bölümü ve BESYO (Beden Eğitimi ve Spor Yüksek Okulu) öğrencilerinin uzaktan eğitime ilişkin düşünce, tutum ve davranışlarıdır. Araştırma Ordu Üniversitesi Sosyoloji bölümü ve BESYO öğrencilerinin uzaktan eğitim hakkındaki görüşleri temelinde sınırlandırılmıştır.

Amaca yönelik örnekleme tekniği ile Sosyoloji bölümü ve BESYO bölümleri araştırmaya dâhil edilmiştir. Bu iki bölümün tercihinde sosyoloji bölümünün teorik ağırlıklı ve BESYO'nun uygulama ağırlıklı olması etkili olmuştur. Örneklem hesaplamalarında azami 255 örneklem sayısı hesaplanmıştır. $\mathrm{Bu}$ kapsamda araştırmaya dâhil edilecek kișinin 255'in altında olmaması planlanmıştır. Araştırma evreninin tamamına ulaşılması amaçlanmakla birlikte Google Form üzerinden internet tabanlı gerçekleștirilen anket uygulamasına 288 öğrenci katılmıştır. Ancak 12 anket tespit edilen sorunlar nedeniyle iptal edilmiş ve 118'i Sosyoloji Bölümü ve 158'i BESYO öğrencisi olmak üzere toplamda 276 öğrenci araştırmaya dâhil edilmiştir.

Araştırmada nicel araştırma tekniklerinden tarama araştırması kullanılmıştır. Anketler Google form üzerinden uygulanmıştır. Anket formu 30 kapalı uçlu ve 3 açık uçlu soru olmak üzere toplam 33 sorudan oluşturulmuştur. Araştırma sonuçları betimsel analiz çerçevesinde değerlendirilmiştir.

Araştırma için Ordu Üniversitesi Sosyal ve Beşeri Bilimler Bilimsel Araştırmaları Etik Kurulundan etik onay (2020-71) alınmıştır. Ayrıca araştırmaya ilişkin bilgilendirilen öğrencilere kişisel bilgilerin gizli tutulacağı ve araştırmaya katılımın gönüllülük esasına dayandığı belirtilerek gönüllü olanlar araştırmaya dâhil edilmiştir.

\section{Salgın Dönemi Uzaktan Eğitime İlişkin Betimsel Bulgular}

Araştırmamıza dâhil olan 276 öğrencinin bilgileri Görsel 1'de verilmektedir. Buna göre 276 öğrencinin 170'i kadın 106'sı ise erkek öğrencilerden oluşmaktadır. Öğrencilerin 118'i sosyoloji bölümü, 158'i ise BESYO öğrencisidir. Birinci sınıf öğrenci sayısı 68, ikinci sınıf öğrenci sayısı 97, üçüncü sınıf öğrenci sayısı 55 ve dördüncü sınıf öğrenci sayısı 56 'dır.

\begin{tabular}{cccc}
\hline & & Sayı & Yüzde \\
\hline Cinsiyet & Kadın & 170 & 61,6 \\
& Erkek & 106 & 38,4 \\
\hline \multirow{2}{*}{ Bölüm } & Sosyoloji & 118 & 42,8 \\
& BESYO & 158 & 57,2 \\
\hline \multirow{3}{*}{ Sınıf } & 1. Sinıf & 68 & 24,6 \\
& 2. Sinıf & 97 & 35,1 \\
& 3.Sınıf & 55 & 19,9 \\
& 4. Sınıf & 56 & 20,3 \\
\hline
\end{tabular}




\section{Görsel 1: Cinsiyet, Bölüm ve Sınıf}

Görsel 2'de öğrencilerin gelir düzeyi, yerleşim yeri ve konut özelliklerine dair veriler yer almaktadır. Buna göre öğrencilerin \%65,2'sinin orta gelir grubuna dâhil olduğu görülmektedir. Yerleşim yeri kapsamında ilçe \%34,8 ile en yüksek orana sahiptir. Konut türünde \%59,8 ile apartman dairesi ve site tarzı konutlar ön plana çıkmaktadır. Öğrenci ailelerinin \%74,3'nün konut sahibi olduğu görülmektedir.

\begin{tabular}{cccc}
\hline & & Sayı & Yüzde \\
\hline \multirow{4}{*}{ Gelir Düzeyi } & Düşük & 18 & 6,5 \\
& Ortanın Altı & 31 & 11,2 \\
& Orta & 180 & 65,2 \\
& Ortanı̈ Üstü & 42 & 15,2 \\
& Yüksek & 5 & 1,8 \\
\hline \multirow{3}{*}{ Yerleşim Yeri } & Köy & 56 & 20,3 \\
& İlçe & 96 & 34,8 \\
& Şehir & 42 & 15,2 \\
Konut Türü & Büyükșehir & 82 & 29,7 \\
& Müstakil Ev & 111 & 40,2 \\
& Apt. Daire/Site & 165 & 59,8 \\
\hline \multirow{3}{*}{ Konut Sahipliği } & Ailenin Kendisinin & 205 & 74,3 \\
& Kira & 67 & 24,3 \\
& Diğer & 4 & 1,4 \\
\hline
\end{tabular}

Görsel 2: Gelir Düzeyi, Yerleşim Yeri ve Konut Özellikleri

Ders takibini gerçekleștirdikleri ortama ilişkin bilgilerin yer aldığı Görsel 3'e göre öğrencilerin \%64,1'nin kendilerine ait odaları vardır. Öğrencilerin yalnız \%5,4'ü ailelerinin sessiz bir ortam sağlamada hiç desteği olmadığını söylemiştir. Tamamen desteklediğini söyleyenlerin oranı ise \%39,9'dur. Rakamlar öğrencilerin yarısından fazlasının sessiz ortam konusunda kısmen veya tamamen destek aldığını göstermektedir (Kısmen, destekliyor ve tamamen destekliyor toplam $\% 85,5^{\prime}$ dir).

3655 veli üzerine yapılan bir çalışmada velilerin \%78,50'si çocuklarına rahatsız edilmeyeceği bir çalışma ortamı sağlayabildiğini düşünürken, \%21,50'si bu ortamı sağlayamadığını düşünmektedir (Yılmaz vd. 2020). Bu sonuçlar bizim çalışmamızla oldukça yakındır.

\begin{tabular}{cccc}
\hline & & Sayı & Yüzde \\
\hline & Üç ve daha az & 52 & 18,8 \\
\multirow{4}{*}{ Konut Kişi Sayısı } & Dört & 93 & 33,7 \\
& Beş & 66 & 23,9 \\
& Altı & 39 & 14,1 \\
& Yedi ve daha fazla & 26 & 9,4 \\
\hline \multirow{2}{*}{ Oda Sayısı } & Bir veya iki odalı & 43 & 15,6 \\
& Üç odalı & 148 & 53,6 \\
Kendine Ait Oda & Dört ve fazla odalı & 85 & 30,8 \\
& Var & 177 & 64,1 \\
& Yok & 99 & 35,9 \\
\hline \multirow{3}{*}{ Aile Destek (Sessiz } & Hiç Destek Yok & 15 & 5,4 \\
Ortam) & Destek Yok & 25 & 9,1 \\
& Kismen & 76 & 27,5 \\
& Destekliyor & 50 & 18,1 \\
& Tamamen Destek & 110 & 39,9 \\
\hline
\end{tabular}

Görsel 3: Ders Takibi Ortamı

Öğrencilerin ders takibi için ihtiyaç duydukları teknolojik özellikler Görsel 4'de gösterilmektedir. Öğrencilerin \%59,1'nin kendisine ait bilgisayarı olmadığı görülmektedir. Ders takibi \%59,8 oranı ile kendilerine ait cep telefonu ile yapılmaktadır. İnternet kullanımında ise $\% 40,2$ ile mobil internet ön plana çıkmaktadır. 


\begin{tabular}{cccc}
\hline Kendine Ait Bilgisayar & Var & 113 & 40,9 \\
& Yok & 163 & 59,1 \\
\hline \multirow{3}{*}{ İnternet Türü } & Ev İnterneti & 65 & 23,6 \\
& Mobil İnternet & 111 & 40,2 \\
& Her İkisi & 100 & 36,2 \\
\hline \multirow{3}{*}{ Ders Takip Türü } & Kendine Ait Bilgisayar/Tablet & 76 & 27,5 \\
& Kendine Ait Cep Telefonu & 165 & 59,8 \\
& Aileye Ait Bil./Tab./Cep Tel. & 35 & 12,7 \\
\hline \multicolumn{3}{c}{ Görsel 4: Teknolojik Özellikleri }
\end{tabular}

Öğrencilerin ders takip ve çalışma düzenine ilişskin verilere bakıldığında (Görsel 5), tüm dersleri takip ettiğini belirtenlerin oranı \%14,9'da kalmaktadır. Arasıra dersleri kaçırdığını belirtenlerin oranı ise \%43,8'dir. Buna göre öğrencilerin yarısından fazlasının $(\% 58,7)$ derslerin çoğunu takip ettiği söylenebilir. Ders tekrarı izleyenlerin oranı ise \%39,5'dir. Ders çalıșma sürelerine bakıldığında ders çalışmaya hiç vakit ayırmadığını söyleyen öğrencilerin \%43,1 oranı dikkat çekmektedir. Bu durum bir motivasyon eksikliğinin göstergesi olabilir. Evde vakit geçirmede ise internet/sosyal medya $(\% 37,7)$ ve ev işleri $(\% 31,2)$ ön plana çıkmaktadır.

\begin{tabular}{|c|c|c|c|}
\hline & & Sayı & Yüzde \\
\hline \multirow{4}{*}{$\begin{array}{l}\text { Canlı Ders Takip } \\
\text { Sıklığ } 1\end{array}$} & Hiç Ders Kaçırmıyorum & 41 & 14,9 \\
\hline & Ara Sıra Dersleri Kaçırıyorum & 121 & 43,8 \\
\hline & $\begin{array}{c}\text { Dersleri Ara Sira Takip } \\
\text { Edebiliyorum }\end{array}$ & 61 & 22,1 \\
\hline & Derslerin Çoğunu Kaçırıyorum & 53 & 19,2 \\
\hline \multirow[t]{2}{*}{ Ders Tekrarı İzleme } & İzliyorum & 109 & 39,5 \\
\hline & İzlemiyorum & 167 & 60,5 \\
\hline \multirow{5}{*}{ Ders Çalışma Süresi } & Hiç Çalıșmıyorum & 119 & 43,1 \\
\hline & Bir Saat & 95 & 34,4 \\
\hline & İki Saat & 37 & 13,4 \\
\hline & Üç Saat & 11 & 4 \\
\hline & Dört ve Fazla & 14 & 5,1 \\
\hline \multirow{6}{*}{$\begin{array}{l}\text { Evde Vakit Geçirme } \\
\text { Biçimi }\end{array}$} & Ev İşleri & 86 & 31,2 \\
\hline & TV İzleme & 13 & 4,7 \\
\hline & İnternet/Sosyal Medya & 104 & 37,7 \\
\hline & Aileyle Aktivite/Sohbet & 43 & 15,6 \\
\hline & Kitap Okuma/Spor vb. & 14 & 5,1 \\
\hline & İște Çalışma & 16 & 5,8 \\
\hline \multirow{5}{*}{$\begin{array}{l}\text { Arkadașlarla } \\
\text { İletişim }\end{array}$} & Hergün & 82 & 29,7 \\
\hline & Haftada İki-Üç Gün & 95 & 34,4 \\
\hline & Haftada Bir & 52 & 18,8 \\
\hline & İki-Üç Haftada Bir & 35 & 12,7 \\
\hline & Hiç & 12 & 4,3 \\
\hline
\end{tabular}

\section{Görsel 5: Ders Takip ve Çalışma Düzeni}

Görsel 6'da öğrencilerin eğitim tercihleri ve nedenleri yer almaktadır. Buna göre öğrencilerin \%92'si yüzyüze eğitimi tercih etmektedir. Bu tercihin nedenlerinde ise ilk sırada \%39,9 ile verimlilik/etkililik gelmektedir. Uzaktan eğitim tercihi yapan 22 öğrenciden 14'ü $(\% 63,6)$ uzaktan eğitim tercihinin nedeni olarak rahatllğa, 3'ü verimliğe/etkililiğe, 2'si ulaşılabilirliğe (tekrar) vurgu yapmaktadır. Yüzyüze eğitim tercihinde bulunanlar ise tercih nedeni olarak sırasıyla verimlilik/etkililik (107 kişi \%42,1), odaklanma/dikkat (33 kişi \%13), anlaşılırlık (30 kişi \%11,8) ve iletişim (25 kişi \%9,8) ifadelerine başvurmaktadır.

\begin{tabular}{cccc}
\hline & & Sayı & Yüzde \\
\hline Eğitim Tercihi & Yüz Yüze & 254 & 92 \\
& Uzaktan & 22 & 8 \\
\hline & Verimlilik/Etkililik & 110 & 39,9 \\
& Anlaşllırlı & 31 & 11,2 \\
Tercih Nedeni & Odaklanma/Dikkat & 34 & 12,3 \\
& İletişim & 25 & 9,1
\end{tabular}




\begin{tabular}{ccc} 
Mekân Uygunluğu & 19 & 6,9 \\
Disiplin & 15 & 5,4 \\
Rahatlık & 14 & 5,1 \\
Sosyallik & 8 & 2,9 \\
Ulaşılabilirlik (İnternet, tekrar izleme) & 20 & 7,2 \\
\hline
\end{tabular}

Görsel 6: Eğitim Tercihi ve Nedenleri

Tercih nedenleri açık uçlu olarak sorulmuş ve sonrasında kategoriler oluşturulmuştur. Uzaktan eğitim tercihinde bulunan öğrencilerin daha çok rahatlık ve dersleri tekrar etme özelliğine vurgu yaptığı görülmektedir. Örneğin bir öğrenci yüzyüze eğitimdeki çekingenliğine vurgu yaparak şunları söylemiştir;

“Çekingenliğim olmuyor bir de ders kayıtları gayet işimize yarıyor daha iyi takip edebiliyorum dersleri tabiki yüzyüze eğitim daha fazla etkilidir ama bence uzem de gayet iyi ben sevdim bir de dersi tek başına dinlemek daha ayrıntılı oluyor hocaya daha yakınsın gayet hoş"

Benzer şekilde bir diğer öğrenci "Daha rahat hissediyorum kendimi derse katılım noktasında çekinmiyorum" ifadesini kullanmıştır.

Uzaktan eğitimde daha verimli olduğunu belirten bir öğrenci ise "Daha çok verim allyorum ve evimde daha rahat ders çalışabiliyorum sınıftaki kalabalık ve yurt ortamı ders çalışma isteğimi düşürüyor." demektedir. Aynı şekilde bir diğer öğrenci uzaktan eğitimin odaklanma konusunda daha iyi olduğunu belirtmektedir; "Dikkatimi dağıtacak herhangi birileri olmuyor ve yalnızca hocaya odaklanıyorum". Tekrar konusuna vurgu yapan öğrenciler ise "Dersi kaçırsakta tekrar izleme imkanı en büyük fark.", "Çalışma ve tekrar dinleme firsatı oluyor" ifadelerini kullanmaktadırlar.

Bazı öğrenciler ise zaman kullanımına değinmektedirler. "Zamanı iyi yönetebilme imkanı sağlaması", "Yolda geçirdiğim zamanı derse girmek için harcıyorum. Kendime daha fazla zaman ayırıyorum" vb. cevaplar zamana vurgu yapan cevaplar arasındadır.

Bir öğrenci ise uzaktan eğitimle yüzyüze eğitimin aynı nitelikte olduğuna değinmektedir. Ayrıca salgın döneminin getirmiş olduğu sorunlar içerisinde derslerde verimlilik aranmasından yakınmaktadır;

"uzaktan eğitim ile yüzyüze eğitimin hiç bir farkı yok ikisinde de anlatılıp geçiliyor yüz yüze eğitimde boş yere kalkıp okula gidiyoruz yol parası masraf derslere zaten yetişilmiyor 15 saniye geç girdiğimiz derse almayan hocalar var en azından böyle o sorunda kalmıyor, uzaktan eğitimin tek zamanı sıkıntısı bütün dünya felaket içinde yanıyor her gün virüsten sadece Türkiye'de yüzlerce insan ölüyor ama uzaktan eğitim var sanki hiç bir sorun yokmuş gibi verimli ders işlenmesi bekleniyor Allah bilir bu işlenen derslerden sinav falan oluruz ve kalırız"

Yüz yüze eğitim tercihinde bulunan öğrenciler ise verimlilik, ev ortamının ders için uygun olmaması, internet sorunları, uzaktan eğitimde tartışma ortamının istenilen düzeyde yapılamaması ve yüzyüze iletişim olanağının uzaktan eğitimle sağlanamaması gibi nedenleri sıralamaktadırlar.

"İmkan açısından hepimiz kısıtlıyız ve eğitim bakımından da büyük bir kaybımız var. Uzaktan eğitim tüm öğrencilere aynı düzeyde eşitlik sağlamıyor bilgisayarı, telefonu, interneti olanlar var birde bunun yanında olmayanlar var örneğin word de çalışılıp şablon hazırlanması gerekiyor bu zorla verilen sorumluluğu sokağa çıkma yasakları varken internet cafeler kapalıyken bilgisayarı olmayan bir birey ne kadar yerine getirir tartışılır. Türkiye gibi eğitime önem veren bir ülkenin eğitimini yaz okuluyla tamamlaması açı̆̆ı ise yüz yüze eğitim ve sınavlarla tamamlaması gerekir. Öğrenciler mağdur edilmemeli eğitim kaldığı yerden devam etmeli"

"Internet üzerinden eğitimde çoğunlukla katılım sağlanamıyor. Sistemde arızalar, internette ki arızalar, elektrik vs çoğunlukla katılım olmuyor ve olunca bile dersleri zor anlıyoruz kesik geliyor ses duraksamalar oluyor"

"Internetten erişiminde kaynaklı olduğu için derslerini dinleyemiyorum ve uzaktan eğitimi verimli bulmuyorum not tutamıorum girdiğim derslerde de tekrarı olmuyor ve 1 saati ver her dersin o saatin yarısı zaten sistemin açılmasıyla doluyor. Yüz yüze bile zor anladığım dersleri uzaktan hiç anlayamıyorum. Burada mağdur öğrenci oluyor böyle bir mağduriyet istemiyorum herkesin bilgisayarı düzenli bir interneti yok o yüzden mağdur oluyorum." 
"bizim evde genelde 4 tane çocuk oluyor hepsi kuzenim 1 i kardeşim yazları 3 ay boyunca 6 çocuk oluyor yaşları 5, 6,7 ve 14 en küçük yeğenim kitaplarımı karıștırıp yerlerini değiş̧iriyor ders dinlerken bağırıyorlar ev kalabalık oluyor yurt rahat"

"Yüz yüze ilişkilerin daha iyi olacağını düşünüyorum çünkü uzaktan eğitim demek tam bir sıkıntı mesela açıyorum bilgisayarı dikkatim illaki dağılıyor ya canım bir șeyler yemek istiyor ya da bir yere dalıyorum göz göze temasın etkileşimi yok, bir iletişim yok böyle olunca da derslerden gereken verimi alamiyorum."

"Online eğitimde verim oranı çok düşük hocayı dersi dinlerken not alırken yakalamak çok zor yüzyüze eğitimde bu tarz sorunlar olmuyor hocayı anında durdurup sormak istediğini sorup yanıt alabiliyorsun ama online da bu pek mümkün değil"

"Yüz yüze hocalarla konuşarak tartışarak fikirlerimizi beyan ederek belli bir düzene sahip olarak daha verimli eğitim alyyoruz"

Bazı öğrenciler ise özellikle uzaktan eğitimde ders devam etme zorunluluğu gibi sorumluluklarının azaldığını bununda verimliliklerini düşürdüğünü belirtmişlerdir.

"Yüz yüze eğitim daha etkili. Öğrencilerin bir sorumluluk alması gerekiyor. Uzaktan eğitim bence çok dikkate alınmıyor, örneğin sabah 10 da olan dersleri bazen uykudan yeni uyanmıss şekilde yatarken takip edenler var ama yüz yüze eğitim olsa en az 1saat önceden kalkıp hazırlanıp okula gidiyorduk, bir disiplin şart."

“Öğrencilerin otoriteye ihtiyacı olduğunu düşünüyorum. Bazı sorumluluklar için somut mekan ve zamana ihtiyaç vardır. Öğrenci uzaktan eğitimde kendini salar ve sorumluluklarını yerine getirmez"

"Yüz yüze eğitimde insanlar derse gitme zorunluluğu hissediyor bu şekilde herkesin katıldığını düşünmüyorum ve yeterli tartışma ortamı sağlanamıyor. Sosyalleşme açısından en önemli görevi okullar üstleniyor online eğitimde insanların yeterli olarak sosyalleșemediğini düşünüyorum."

"Öğrencilere sınırlama getirmezseniz başarı oranları çok düşer uzaktan eğitime katılma zorunluluğu olmadığı için örgün eğitim daha mantıklı olur"

"Uzaktan eğitim de katılma zorunluluğu yoktur bu bizi derslerden daha çok uzaklaştırdığı için örgün eğitim daha iyi"

Ayrıca bazı öğrenciler evde kendilerine başka sorumluluklar yüklenmesinin ders verimliliğini düşürdügünü ifade etmektedir.

"Adapte olamıyorum. Internetten kaynaklı kesintilerden dolayı bazı cümle ve kelimeleri kaçırmam doğrultusunda devamını anlayamıyorum. Ev iși ve okul hayatı birbirine karışlyor bazen kendimi ders dinlerken bulaşık yılkyor olarak buluyorum"

"Okula gidebildiğiniz için dışarıdan herhangi bir sorumluluk size yüklenmiyor. Sadece okul ile meşgul olabiliyorsunuz."

Görsel 7'de uzaktan eğitimin kalitesi ve verimliliğine ilişkin veriler yer almaktadır. Öğrencilerin uzaktan eğitimin kalitesini orta düzeyde değerlendirdiği görülmektedir $(\% 40,2)$. Verimliliğin ise düşük düzeyde olduğu belirtilmektedir (\%30,4 çok verimsiz ve \%32,9 verimsiz). Bu kapsamda öğrencilerin yarıdan fazlası kendisini öğrenci gibi hissetmemektedir $(\% 55,8)$. Gelecekte uzaktan eğitimin kalıcı olması durumuna ise öğrencilerin çoğunluğu katılmamaktadır $(\% 61,2)$. Öğrencilerin tüm teknolojik gelişmelere rağmen gelecekte okulun eğitim için önemli bir unsur olarak kalacağını düşündükleri söylenebilir.

\begin{tabular}{cccc}
\hline & & Sayı & Yüzde \\
\hline & Çok Kötü & 39 & 14,1 \\
Uzaktan Eğitim & 2 & 71 & 25,7 \\
Kalite & 3 & 111 & 40,2 \\
& 4 & 44 & 15,9 \\
& Çok İyi & 11 & 4 \\
\hline Çok Verimsiz & 84 & 30,4 \\
& 2 & 88 & 31,9 \\
3 & 73 & 26,4
\end{tabular}




\begin{tabular}{cccc} 
Uzaktan Eğitim & 4 & 24 & 8,7 \\
Verimlilik & Çok Verimli & 7 & 2,5 \\
\hline Kendini Öğrenci & Evet & 18 & 6,5 \\
Hissetme & Kismen & 104 & 37,7 \\
& Hayır & 154 & 55,8 \\
\hline & Tamamen & 169 & 61,2 \\
Gelecekte & Katılmıyorum & & \\
Uzaktan Eğitim & 2 & 34 & 12,3 \\
Olasılığı & 3 & 46 & 16,7 \\
& 4 & 15 & 5,4 \\
& Tamamen Katılıyorum & 12 & 4,3 \\
\hline
\end{tabular}

Görsel 7: Uzaktan Eğitimin Kalitesi ve Verimliliğine Dair Düşünceler

Görsel 8'de öğrencilerin kendileri ve hocaların uzaktan eğitim performansına ilişkin düşünceleri yer almaktadır. Buna göre öğrenciler uzaktan eğitimin kendi performanslarını azalttığı $(\% 80,1)$ görüşündedirler. Hocalar açısından ise performanslarında bir değişim görmemektedirler $(\% 52,9)$.

\begin{tabular}{cccc}
\hline Uzaktan Eğitimin & & Sayı & Yüzde \\
\hline Kendi Performansına & Azaltıyor & 221 & 80,1 \\
Etkisi & Değişiklik Yok & 43 & 15,6 \\
& Artıyor & 12 & 4,3 \\
\hline Hocaların & Azaltıyor & 117 & 42,4 \\
Performansına Etkisi & Değişiklik Yok & 146 & 52,9 \\
& Artıyor & 13 & 4,7 \\
\hline
\end{tabular}

Görsel 8: Uzaktan Eğitimin Performans Değerlendirmesi

Görsel 9'da uzaktan eğitimin avantaj ve dezavantajına iliş̧in görüşler yer almaktadır. Avantaj olarak ev rahatlığı $(\% 31,5)$ ve derslerin salgın döneminde devam edebilmesi $(\% 17,4)$ ön plana çıkmaktadır. Avantajı yok diyenlerin oranı ise $\% 23,6$ 'dır. Yüzyüze eğitim tercihi yapan öğrencilerin 82 'si $(\% 32,3)$ ev rahatlığını, 47'si $(\% 18,5)$ derslerin devam etmesini, 29'u $(\% 11,4)$ ders tekrarını, 14'ü $(\% 5,5)$ esnek zamanı, 9'u $(\% 3,5)$ maddiyatı, 6'sı $(\% 2,4)$ daha net/hızlı ders yapılmasını uzaktan eğitimin avantajı olarak belirtirken 63 'ü $(\% 24,8)$ avantajı olmadığını ifade etmektedir. Uzaktan eğitim tercihi yapan öğrencilerin (22 kişi) ise 6'sı esnek zamanı, 5'i ders tekrarını, 5'i ev rahatlığını, 3'ü daha net/hızlı ders yapılmasını, 1'i ise salgın dönemi derslerin devam etmesini avantaj olarak görmekteyken, 2'si avantaj yok ifadesini kullanmaktadır.

Uzaktan eğitimin dezavantajları olarak \%22,8 ile internet sorunları ve \%19,9 ile verimsizlik ilk iki sırada yer almaktadır. Onları disiplin eksikliği/rahatlık $(\% 11,2)$ ve dikkat/odaklanma $(\% 10,5)$ izlemektedir. Yüzyüze eğitim tercihi yapan kişilerin 54'ü $(\% 21,3)$ internet sorunlarını, yine 54'ü $(\% 21,3)$ verimsizliği, $33^{\prime}$ ü $(\% 13)$ dikkat/odaklanma sorununu, 29'u $(\% 11,4)$ disiplin eksikliği/rahatlığı ve 27 'si tartışma ortamı/iletişim eksikliğini uzaktan eğitimin dezavantajı olarak göstermektedir. Dersi anlayamama (17 kişi), uygulamalı derslerin yapılamaması (6 kişi), asosyallik (12 kişi) ifadelerinin tamamı yüzyüze eğitim tercihi yapan öğrenciler tarafından kullanılmıștır. Uzaktan eğitim tercihi yapan 22 öğrenciden 9'u $(40,9)$ dezavantaj olarak internet sorunlarına değinirken 6'sı $(\% 27,3)$ dezavantaj yok ifadesine başvurmaktadır. Diğer taraftan iki öğrenci tartışma ortamı/iletişim eksikliğine, iki öğrenci ise disiplin eksikliğii/rahatlı̆ga değinmektedir.

\begin{tabular}{cccc}
\hline & & Sayı & Yüzde \\
\hline & Avantajı Yok & 65 & 23,6 \\
Uzaktan Eğitim & Derslerin Devam Etmesi (salgın) & 48 & 17,4 \\
Avantaj & Ders Tekrarı & 34 & 12,3 \\
& Esnek Zaman & 20 & 7,2 \\
& Ev Rahatlığı & 87 & 31,5 \\
Maddiyat & 9 & 3,3 \\
& Yoklama, Geç Kalma & 4 & 1,4 \\
& Daha Net, Hızlı Ders & 9 & 3,3 \\
\hline Dezavantajı Yok & 12 & 4,3 \\
& Internet Sorunları & 63 & 22,8 \\
& Dikkat/Odaklanma & 34 & 12,3
\end{tabular}




\begin{tabular}{cccc} 
Uzaktan Eğitim & Tartışma Ortamı/İletişim Eks. & 29 & 10,5 \\
Dezavantaj & Verimsizlik & 55 & 19,9 \\
& Dersi Anlayamama & 17 & 6,2 \\
& Uygulamalı Dersler & 6 & 2,2 \\
& Disiplin Eksikiliği/Rahatlık & 31 & 11,2 \\
& Sosyalleşememe & 12 & 4,3 \\
& Uygun Ortam Eksikiliği & 17 & 6,2 \\
\hline
\end{tabular}

Görsel 9: Uzaktan Eğitimin Avantaj ve Dezavantajları

Uzaktan eğitimin avantaj ve dezavantajları açık uçlu olarak sorulmuştur. Bu kapsamda uzaktan eğitim tercihi yapan öğrenciler tekrar, ev ortamının rahatlığı ve zaman verimliliği açısından değerlendirme yapmaktadırlar. "Dersin kayıt edilmesi", "Ders tekrarlarını izleyebilmem daha rahat not çıkarabilmem", "Daha sonra izleyebilmek", "Tekrar tekrar izlenebilmesi” ders kayıtlarına vurgu yapan ifadelerdir. "Zaman", "Zaman kaybetmek yok", "Zaman konusunda avantajı var", "Yolda zaman harcamıyorum", "Net, hızlı" zaman verimliliğine, "Evde olmak", "Ailenin yanında olmak ve sorumluluğun azalması", "Ev ortamı olması (rahatlık)" ise ev ve rahatlığa vurgu yapan ifadelerdir. Bir öğrenci "Birebir özel ders almak gibi geliyor" ifadesini kullanarak uzaktan eğitimi özel ders almaya benzetmektedir. Bir başka öğrenci ise "Öğrenciler derse odaklanmak da daha kaliteli yaklaşabilir dikkati dağılmaz ve sadece hocaya odaklanır dersi daha iyi takip edebilir (bence)" ifadesiyle uzaktan eğitimin odaklanmada sınıf ortamının dikkat dağıtan unsurlarından arınmış olması nedeniyle daha verimli olabileceğine dikkat çekmektedir.

Uzaktan eğitim tercihi yapan öğrenciler açısından uzaktan eğitimin dezavantajı olmadığı ifade edilmekte ya da internet kaynaklı sorunlar dezavantaj olarak belirtilmektedir. Bu kapsamda uzaktan eğitim tercihi yapan öğrenciler "Arada bir sistemin arıza yaşaması ve internet sıkıntısı yaşayan öğrencilerin ders takibi yapamaması", "hiç bir dezavantajı yok yüz yüze eğitimden tek farkı yapıldığı zamanın kaos içinde olması", "Yoğunluk olduğunda siteye girememe ve sitenin aşırı yavaş olması", "Hocalarımızın ses ve görüntüsünün donması" türünden ifadeler kullanmışlardır.

Yüz yüze eğitim tercihi yapan öğrenciler uzaktan eğitimin avantajı olmadığına ya da salgın döneminde en azından eğitimin devam etmesi, ders tekrarı izleyebilme ve ev rahatlı̆̆ına vurgu yapmaktadırlar. Bu kapsamda "Şu an ki yaşadığımız olumsuz durumu en az indirmek için iyi bir yöntem", "Bu zor günde en yüksek kalitede dersleri dinlememizi sağlayıp derslerden geri kalmamamızı sağlıyor", "Bu dönemde dersleri salmamamız için iyi oldu" vb. ifadeler salgın döneminde eğitimin devam etmesine değinen ifadeler olarak öne çıkmaktadır. "Normal örgün eğitimle birlikte olsa çok avantajı var ama şuan tek avantajı tekrar izlenebiliyor olması", "Derslerde kaçırdığım yerleri tekrar dinleyebiliyorum" vb. ifadeler ise ders tekrarına vurgu yapmaktadır. Ayrıca "Evde aile üyeleri ile birlikte olmak", "üniversitenin stresi yok üzerimizde", "Tek avantajı yatağımızdan erken saatte kalkmamamız", "Öğretmen iktidarını hissetmemek", "Ders dinliyor gibi durup kamera kapatarak herşeyi yapmak" vb. rahatlık vurgusu yapan ifadelerdir. Ancak bazı öğrenciler tarafından rahatlık avantaj olarak tanımlanmakla birlikte bu avantajın geniş bir perspektifle düşünüldügünde avantaj olup olmadığı tartışmalıdır; "Uzaktan eğitimin en iyi avantajı rahat bir şekilde ders dinlemek bu da avantaj olur mu tartışılır tabi iyi bir ders için disiplin gerekli”. Bir öğrenci "Tek avantajı yüzyüze eğitimin klymetini daha çok bildirdi" ifadesini kullanmaktadır. Diğer bir öğrenci ise uzaktan eğitimin okulun teknolojik altyapısının farkına varmasındaki etkisine değinmektedir; "Bu sayede üniversite altyapısı olarak bilişim teknolojilerinden faydalanabilip hayata uyarlayabilecek kapasitede bir üniversite olduğumuzu anlamış olduk".

Yüz yüze eğitim tercihinde bulunan öğrencilerin uzaktan eğitimin dezavantajlarına ilişkin görüşleri ise internet sorunları, derslerden verim alınamaması, sosyalleşmenin olmaması, hocalarla iletişim kuramama, dikkat ve odaklanma sorunu gibi ifadelerden oluşmaktadır. "Herkes bilgisayarın başına oturup rahat bir șekilde ders dinleyemiyor bazılarının neti yok bilgisayarı yok hadi bunlar olsa ailesi anlayışlı olmayabilir bunlar da hallolsa bilgisayarın başına oturup not tutup ders dinleyen öğrenci sayısı az çünkü gereken iletişim yok, sınıf ortamı yok", "Hocalarla ve arkadaşlarımızla iletişimimiz kopuk oluyor", "Yeterli tartışma ortamı sağlanamıyor", "Sınıftaki gibi düşüncelerimizi paylaşamıyoruz sınıf ortamı olmadan dikkatim dağılıyor", "Bilgisayar, telefon, tablet gibi elektronik aletlere sürekli bakmak ve hocayla göz teması kuramamak dikkat dağılmasına dersin verimsiz olmasını sağlıyor", "Eğitim olarak yüz yüze dersi savunuyorum. İnsan sınıfortamında disiplin olarak psikolojiye bürünerek, dikkat dağılma seviyesi en az seviyedeyken ders dinliyor. Fakat uzaktan eğitimde öyle değil. Dersi 
dinlediğimiz yerde dikkatimizi dağıtacak etkenler sınıfa nazaran daha fazla. Ayrıca online eğitime gerek maddi gerek manevi olarak şartları yetersiz olan öğrenciler olabileceğini düşünüyorum. Fakat şuan içinde bulunduğumuz zorunlu şartlar buna dahil değildir tabi ki" gibi ifadeler uzaktan eğitimin dezavantajlarına ilişkin birkaç örnektir. Bunlara ek olarak uzaktan eğitimin sağladığı rahatlığın dezavantaj yarattı̆̆ına ilişkin ifadelerde bulunmaktadır. Örneğin, "Kendimi okuldaki gibi bir disiplin anlayışında hissedemiyorum evde olduğum için daha rahat davranma eğilimi içinde olabiliyorum. Ev işleri ile uğraşmak zorundayım çünkü", "Devamsızlık sorunu yok diye kendimi derslere katılmaya mecbur hissetmiyorum", "Yüz yüze olan dersler kadar önemsenmemesi. Çünkü hocalar seni görmüyor, kimi sisteme giriş yapıyor ve dersi dinlemiyor", "Derslere duyulan önemin isteğin azalması" vb. ifadelerle ev ortamındaki rahatlığın disiplin kazanmada ve derslere verilen önemde azalmalara yol açabileceği belirtilmektedir. Ayrıca bazı öğrenciler uygulama derslerine vurgu yaparak "Uygulamalı derslerimizi sadece teorik şekilde işliyoruz", "Uygulama derslerimizi işleyemiyoruz", "Kesinlikle kimse bir şey anlamayacak uygulama dersler özellikle nasıl işleniyor tabi ki sadece tanım yapıllyor o yüzden uygulama dersler konusunda kötü" vb. ifadeler kullanmaktadırlar.

\begin{tabular}{cccc}
\hline & & Sayı & Yüzde \\
\hline Yakınlardan & Var & 41 & 14,9 \\
Salgına Yakalanma & Yok & 235 & 85,1 \\
\hline \multirow{2}{*}{ Sosyal Mesafeye } & Tamamen & 3 & 1,1 \\
Uyma & Uymuyorum & & \\
& 2 & 9 & 3,3 \\
& 3 & 31 & 11,2 \\
& 4 & 81 & 29,3 \\
Duygusal Duruma & Tamamen Uyuyorum & 152 & 55,1 \\
\hline \multirow{2}{*}{ Etki } & Evet, Oldu & 228 & 82,6 \\
& Hayır, Olmadı & 48 & 17,4 \\
\hline & Son Derece Olumsuz & 60 & 21,7 \\
Etki & 2 & 90 & 32,6 \\
& 3 & 105 & 38 \\
& 4 & 15 & 5,4 \\
& Son Derece Olumlu & 6 & 2,2 \\
\hline
\end{tabular}

Görsel 10: Salgının Etkileri

Görsel 10'da öğrencilerin salgına ilişkin düşüncelerine yer verilmektedir. Öğrencilerin çoğunluğu $(\% 82,6)$ salgından duygusal olarak etkilendiklerini belirtmektedir. Ayrıca büyük çoğunluğu ekonomik bakımdan salgından olumsuz etkilendiğini ifade etmektedir. Bu kapsamda salgının duygusal ve ekonomik olumsuzluklarının öğrencilerin motivasyonlarını olumsuz etkilediği söylenebilir. Hali hazırda alışılmış geleneksel yüzyüze eğitim dışındaki bir eğitim tarzına alışmak bir zorluk getirmekteyken, salgının duygusal ve ekonomik olumsuzlukları öğrencilerin sırtına daha fazla yük bindirmektedir. Bu durum uzaktan eğitim konusundaki olumsuz görüşleri bir ölçüde etkilemiş olabilir.

\section{Tartışma}

Çalışmamızda elde edilen sonuçlara göre öğrencilerin büyük çoğunluğu (\%92) yüz yüze eğitimi tercih etmektedir. Öğrencilerin \%62,3'ü uzaktan eğitimi çok verimsiz ya da verimsiz görmektedir. Kendini öğrenci hissetme oranı ise yalnızca \%6,5'dir. Gelecekte uzaktan eğitimin geleneksel eğitimin yerini alacağı düşüncesine tamamen katılmayan/katılmayan öğrencilerin oranı \%73,5'dir. Bu sonuçlar alandaki diğer çalışmalarla uyumlu gözükmektedir.

Necmettin Erbakan Üniversitesi Sağlık Bilimleri Fakültesi Fizyoterapi ve Rehabilitasyon Bölümünde öğrenim gören 265 (216 klz \%81,50, 49 erkek \%18,49) öğrencinin \%90,3'ü yüz yüze eğitimi tercih etmektedir. Öğrencilerin \%87,5'i uygulamalı dersler için, \% 78,5'i ise teorik dersler için uzaktan eğitimin verimliliğini düşük bulmaktadır (Yılmaz, 2020). 593 Spor Bilimleri öğrencisi üzerine yapılan bir çalışmaya göre ise "İzolasyon günleri olmasaydı normal şartlarda uzaktan eğitimi ister miydiniz?" sorusuna hayır diyenlerin oranı $(n=453) \% 76,5^{\prime}$ tir (Aktaş vd. 2020, s. 5). Bir diğer araştırmada (Erzincan Binali Yıldırım Üniversitesi, iktisadi ve idari bilimler fakültesi, sağlık yönetimi bölümünde yapılan araştırma) elde edilen sonuçlara göre, öğrenciler (toplam 254 öğrenci) çevrimiçi (online)/uzaktan eğitim yaklaşımını sıkıcı $(\% 46,7)$ bir yöntem olarak düşünmektedirler. Muhasebe 
derslerini Covid-19 pandemi dönemi sonrasında çevrimiçi (online)/uzaktan eğitim yaklaşımıyla almak istememektedirler $(\% 57,5)$ (Serçemeli ve Kurnaz, 2020). Pamukkale üniversitesinde 2835 öğrenci üzerine yapılmış bir çalışmada öğrenciler pandemi döneminde çevrimiçi öğretim faaliyeti kararlarını daha olumlu karşılarken, pandemi sonrası uzaktan eğitime devam edilmesi konusunda olumsuz görüşler belirtmektedirler (Sarıtaş ve Barutçu, 2020). 3655 veli üzerine yapılan bir çalışmada ise örgün eğitim daha değerli görülmektedir (\%92,40) (Yılmaz vd. 2020). Türkiye dışındaki bazı ülkelerde yapılan çalışmalarda da benzer sonuçlar görülmüştür. Örneğin Pakistan'da yapılan bir araştırmada öğrencilerin çoğunun (\% 71,4) çevrimiçi öğrenmenin geleneksel öğrenmeden daha motive edici olduğu fikrine karşı oy kullandığı görülmektedir (Adnan ve Anwar, 2020).

Araștırmamızın önemli görülen sonuçlarından biri de uzaktan eğitimin avantaj ve dezavantajlarına ilişkin görüşlerdir. Öğrenciler yoğun olarak salgın dönemi derslerin devam etmesini, ders kayıtlarını tekrar izleyebilme özelliğini ve ev rahatlığını uzaktan eğitimin avantajları olarak görmektedir. Dezavantaj olarak ise internet sorunları, verimsizlik, dikkat/odaklanma sorunları ve iletişim eksikliği gösterilmektedir.

Uzaktan eğitimin avantaj ve dezavantajlarına ilişkin elde edilen verilerin diğer çalışmalarla benzerlikler gösterdiği görülmektedir. Literatürde yer alan çalışmalarda tekrar dinleyebilme, rahatlık, verimlilik ve derslere devam edebilme avantaj olarak, odaklanma sorunları, sosyalleşme, hocalarla iletişim kurma sorunları dezavantaj olarak ön plana çıkmaktadır (Arı ve Kanat, 2020; Ekiz, 2020; Karatepe vd., 2020).

Akademisyen ve öğretmenler üzerine yapılan çalışmalarda da tekrar izleme özelliği, teknolojiyi kullanmayı teşvik etmesi, öğrencileri araştırmaya teşvik etme, salgın dönemi derslerin devam edebilmesi ve rahatlık avantaj olarak belirtilirken, etkileşim azlığı, dikkat dağınıklığı, internet sorunları, derse katılım düşüklüğü ve kontrol sorunları dezavantajlar olarak dile getirilmektedir (Bakioğlu ve Çevik, 2020; Çakı ve Akyavuz, 2020; Doğan ve Koçak, 2020; Fidan, 2020; Kurnaz ve Serçemeli, 2020). Okul yöneticileri ise çoğunlukla iletişimden kaynaklı sorunlar yaşadıklarını belirtmişlerdir (Akyavuz ve Çakın, 2020).

Yurt dışında yapılan birkaç örnek çalışmada salgın dönemi derslerin devam edebilmesi, öğrencileri cesaretlendirmesi, öğrencileri daha teşvik edici olması, tekrar izleme imkanı ve rahatlık avantaj olarak, internet sorunları, yüksek maliyetli teknolojik ihtiyaçlar, uygulamalı derslerin yapılamaması, konsantrasyon düşüklüğü, disiplin sorunları, ödev ve sınavlarda karşıllaşllan sorunlar dezavantaj olarak belirtilmektedir (Demuyakor, 2020; Moawad, 2020; Mukhtar et. al, 2020).

Pandemi öncesi yurt dışında gerçekleştirilen bir çalışmanın sonuçları ise avantaj ve dezavantajlar konusundaki düşüncelerin yalnızca pandemi dönemiyle sınırlı olmadığını göstermektedir. 2014 yılında yüzyüze ve çevrimiçi kursları tercih eden öğrenciler üzerine yapılan bu araştırmaya göre öğrenciler, çevrimiçi kurslarda eğitmen varlığının daha düşük seviyelerde olduğunu ve "kendi kendilerine öğretmeleri" gerektiğini bildirmektedirler. Bu nedenle çoğu öğrenci yalnızca "kolay" akademik konuları çevrimiçi olarak almayı tercih ederken "zor" ya da "önemli" konuları yüz yüze almayı tercih etmektedir. Öğrenciler, çevrimiçi kurs alma nedenlerini esneklik, evde rahatlık, zaman tasarrufu ve verimlilik olarak belirtmektedirler. Genel olarak, çoğu öğrencinin çevrimiçi öğrenmenin sağladığı esnekliği ve evde konaklamayı büyük ölçüde takdir etmesine rağmen, çok azı eğer mümkünse tüm derslerini çevrimiçi olarak alacaklarını söylemektedir. Öğrenciler, en azından bazı dersleri yüz yüze alma nedenleri olarak ise kampüs ve akranları ile bağlantı kurmayı ve daha güçlü öğrenci-eğitmen bağlantısını işaret etmektedir. Eğitmenin etkisinin azalması, dersin zor ve önemli olarak görülmesi öğrencilerin yüz yüze eğitimi tercih etmelerini destekleyen unsurlardır (Jaggars, 2014). Çalışmamızda elde ettiğimiz avantaj ve dezavantajına ilişkin düşünceler pandemi öncesi yapılan bu araştırma ile benzer gözükmektedir.

\section{Sonuç}

Teknoloji toplumları değiştiriyor. Aile, siyaset, din, ekonomi, eğitim olmak üzere temel kurumlar ve tüm sosyal ilişkiler değişime uğruyor. Bu değişimin bilgisayar teknolojisinin ve internetin gelişmesiyle daha da hızlandığı söylenebilir. Eğitim kurumu ve okul hem teknolojiyi ortaya çıkaran bilginin üreticisi konumunda olması hem de teknolojiyle daha ilgili olan genç kuşakları içermesi sebebiyle toplumsal değişmelere daha hassastır. Bu kapsamda 90'lar sonrası gelişen teknolojiyle 
beraber eğitimin gelecekte çok köklü değişimlere uğrayacağı yönünde düşünceler üretilmektedir. Özellikle okulun yapısında değişimler ve eğitimin internetle okul dışına çıkarak tüm yaşamı kapsayan bir dönüşümü öngörülmektedir (Doğan, 2012, s. 428). Bu öngörü ya da düşüncelerin bir ölçüde gerçekleștiği de söylenebilir. Okullar hala önemini korumakla beraber, sanal ortamda kursların, derslerin, konferansların yapıldığına tanık olmaktayız. İnsanlar gitmeyi hayal edemedikleri ülke ve üniversitelerden bu şekilde dersler alabilmekteler. Gelecekte bunun çok daha ilerisinde bir değiş̧imin olması ihtimali yüksek görünmektedir.

Kısaca eğitim kurumundaki var olan değişim salgın dönemiyle daha görünür hale geldi. Tüm dünyada etkisini gösteren salgınla beraber uzaktan eğitim uygulamaları hızlı bir şekilde devreye girdi. Türkiye bu duruma en hızlı ve olumlu cevap veren ülkelerden biri oldu. Hiç kuşkusuz teknolojiyi salgın öncesi yoğun olarak kullanan ülke ve okulların süreci daha sağlıklı yürüttügü görülmektedir. Ancak Türkiye'nin salgın döneminde eğitimi yönetme konusunda ön sıralarda yer aldığını söylenebilir.

$\mathrm{Bu}$ kapsamda Ordu üniversitesinde sosyoloji ve BESYO öğrencilerini kapsayan bu araştırma öğrencilerin gözünden eğitim kurumundaki değişimi ortaya koymaya çalışmaktadır. Araştırma sonuçları öğrencilerin salgın dönemi açısından uzaktan eğitimi orta düzeyde başarılı bulduğunu göstermektedir. Ancak öğrencilerin büyük çoğunluğu yüz yüze eğitimi tercih etmektedirler. Dolayısıyla okulun öğrenciler için önemini koruduğu görülmektedir. Öğrencilerin yüz yüze eğitim tercihi nedenlerinde ve uzaktan eğitimin dezavantajlarında sosyalleşme, hocalarla iletişim, derslerde etkileşim ve disiplin gibi ifadelere başvurmaları okulun eğitimin önemli bir parçası olduğunu kanıtlamaktadır. Araştırma sonuçları gelecekte de okulun mevcut önemini öğrenciler adına koruyacağını göstermektedir. Bunun en önemli nedeni de eğitimin insan ilişkileri temelinde yapılmasıdır. Açıklı uçlu sorularda iletişim, sosyalleşme, derslerde etkileşim gibi cevaplar eğitimin insani özelliklerini vurgulamaktadır. Bu temelde yüzyüze eğitimin vermiş olduğu etkileşimi teknolojinin tam olarak sağlayabilmesi pek mümkün görülmemektedir.

Sonuç olarak salgın dönemi bizlere uzaktan eğitimi daha iyi deneyimleyerek olumlu ve olumsuz yönlerini görmememizi sağlamıştır. Bu kapsamda yürütülen çalışmaların da yol göstericiliğiyle gelecekteki eğitim modeline daha hazır hale geleceğimiz söylenebilir.

\section{Kaynakça}

Aktaş, Ö. vd. (2020). Covıd-19 Virüsünden Kaynaklanan İzolasyon Günlerinde Spor Bilimleri Öğrencilerinin Uzaktan Eğitime Karşı Tutumları. Sivas Cumhuriyet Üniversitesi Spor Bilimleri Dergisi, 1(1), 1-9.

Akyavuz, K. E. ve Çakın, M. (2020). Covid-19 Salgınının Eğitime Etkisi Konusunda Okul Yöneticilerinin Görüşleri. Turkish Studies, 15(4), 723-737.

Adnan, M. and Anwar, K. (2020). Online Learning Amid The COVID-19 Pandemic: Students' Perspectives. Journal of Pedagogical Sociology and Psychology, 2(1), 45-51.

Arı, A. G. ve Kanat, M. H. (2020). Covid-19 (Koronavirüs) Üzerine Öğretmen Adaylarının Görüșleri. Van Yüzüncü Yıl Üniversitesi Sosyal Bilimler Enstitüsü Dergisi, Salgın Hastalıklar Özel Sayısı, 459-492.

Bakioğlu, B. ve Çevik, M. (2020). COVID-19 Pandemisi Sürecinde Fen Bilimleri Öğretmenlerinin Uzaktan Eğitime İlişkin Görüşleri. Turkish Studies, 15(4), 109-129.

Banar, K. ve Fırat, M. (2015). Bütüncül Bir Bakıştan Açık Ve Uzaktan Eğitim: Türkiye Özeli, MEB Yenilik ve Eğitim Teknolojileri Genel Müdürlüğü Dergisi, Yeğitek Uzaktan Eğitim Özel Sayısı $12,18-21$.

Bozkurt, A. (2020a). Koronavirüs (Covid-19) Pandemi Süreci Ve Pandemi Sonrası Dünyada Eğitime Yönelik Değerlendirmeler: Yeni Normal Ve Yeni Eğitim Paradigması. Açıköğretim Uygulamaları ve Araştırmaları Dergisi, 6(3), 112-142.

Bozkurt, V. (2020b). Pandemi Döneminde Çalışma: Ekonomik Kaygılar, Dijitalleşme ve Verimlilik. D. Demirbaş vd. (Ed). Covıd-19 Pandemisinin Ekonomik, Toplumsal Ve Siyasal Etkileri (içinde 115-136). İstanbul: İstanbul Üniversitesi Yayınevi. 
Çakın, M. ve Akyavuz, K. E. (2020). Covid-19 Süreci Ve Eğitime Yansıması: Öğretmen Görüşlerinin İncelenmesi. International Journal of Social Sciences and Education Research, 6(2), 165-186.

Demuyakor, J. (2020). Coronavirus (COVID-19) and Online Learning in Higher Institutions of Education: A Survey of the Perceptions of Ghanaian International Students in China. Online Journal of Communication and Media Technologies, 10(3), https://doi.org/10.29333/ojcmt/8286

Di Pietro, G., Biagi, F., Costa, P., Karpiński Z., Mazza, J (2020). The Likely Impact Of COVID-19 On Education: Reflections Based On The Existing Literature And International Datasets. EUR 30275 EN, Publications Office of the European Union, Luxembourg , 2020, ISBN 978-92-7619937-3, doi:10.2760/126686, JRC121071

Doğan, İ. (2012). Eğitim Sosyolojisi, 2. Basım. Ankara: Nobel Yayınları.

Doğan, S. ve Koçak, E. (2020). EBA Sistemi Bağlamında Uzaktan Eğitim Faaliyetleri Üzerine Bir İnceleme. Ekonomi ve Sosyal Araştırmalar Dergisi, 7(14), 110-124.

Ekiz, M. A. (2020). Beden Eğitimi Ve Spor Yüksekokulu Öğrencilerinin Karantina Dönemindeki Uzaktan Eğitim İle İlgili Görüşleri (Nitel Bir Araştırma). Spor ve Rekreasyon Araștırmaları Dergisi, 2(ÖS1), 1-13.

Eroğlu, F. ve Kalaycı N. (2020). Üniversitelerdeki Zorunlu Ortak Derslerden Yabancı Dil Dersinin Uzaktan ve Yüz Yüze Eğitim Uygulamalarının Karşılaştırılarak Değerlendirilmesi. Türk Eğitim Bilimleri Dergisi, 18 (1), 236-265.

Fidan, M. (2020). Covid-19 Belirsizliğinde Eğitim: İlkokulda Zorunlu Uzaktan Eğitime İlişkin Öğretmen Görüşleri. Ușak Üniversitesi Eğitim Araştırmaları Dergisi, 6(2), 24-43.

Jaggars, S. S. (2014). Choosing Between Online and Face-to-Face Courses: Community College Student Voices. American Journal of Distance Education, 28(1), 27-38.

Jena, P. K. (2020). Impact of Covid-19 on Higher Education in India. International Journal of Advanced Education and Research. 5(3), 77-81.

Karakaş, M. (2020). Covid-19 Salgınının Çok Boyutlu Sosyolojisi ve Yeni Normal Meselesi. İstanbul Üniversitesi Sosyoloji Dergisi, 40(1), 541-573.

Karatepe, F. vd. (2020). Öğretmen Adayları Senkron Uzaktan Eğitime Nasıl Bakıyor? Bir Anket Çalışması. Journal of Social and Humanities Sciences Research, 7(53), 1262-1274.

Kurnaz, E. ve Serçemeli, M. (2020). Covid-19 Pandemi Döneminde Akademisyenlerin Uzaktan Eğitim ve Muhasebe Eğitimine Yönelik Bakış Açıları Üzerine Bir Araştırma. USBAD Uluslararası Sosyal Bilimler Akademi Dergisi, 2(3), 262-288.

Moawad, R. A. (2020). Online Learning During the COVID- 19 Pandemic and Academic Stress in University Students. Revista Românească Pentru Educaţie Multidimensională, 12(1), 100107.

Mukhtar, K. et. al (2020). Advantages, Limitations and Recommendations for Online Learning During COVID-19 Pandemic Era. PakJ Med Sci, 36(COVID19-S4), 27-31.

Özbay, Ö. (2015). Dünyada Ve Türkiye'de Uzaktan Eğitimin Güncel Durumu. Uluslararası Eğitim Bilimleri Dergisi, 2 (5), 376-394.

Sarıtaş, E. ve Barutçu, S. (2020). Öğretimde Dijital Dönüşüm Ve Öğrencilerin Çevrimiçi Öğrenmeye Hazır Bulunuşluluğu: Pandemi Döneminde Pamukkale Üniversitesi Öğrencileri Üzerinde Bir Araștırma. Internet Uygulamaları ve Yönetimi, 11(1), 5-22.

Serçemeli, M. ve Kurnaz, E. (2020). Covıd-19 Pandemi Döneminde Öğrencilerin Uzaktan Eğitim ve Uzaktan Muhasebe Eğitimine Yönelik Bakış Açıları Üzerine Bir Araştırma. Journal of International Social Sciences Academic Researches Dergisi, 4(1), 40-53.

Tezcan, M. (2016). Eğitim Sosyolojisi, 16. Baskı. Ankara: Anı Yayıncılık.

UN (United Nations) (2020). Policy Brief: Education During COVID-19 And Beyond. August. 
Yılmaz, E. vd. (2020). Veli Algısına Göre Pandemi Dönemi Uzaktan Eğitim Sürecinin Niteliği, Konya: Palet Yayınları.

Yılmaz, N. A. (2020). Yükseköğretim Kurumlarında Covıd-19 Pandemisi Sürecinde Uygulanan Uzaktan Eğitim Durumu Hakkında Öğrencilerin Tutumlarının Araştırılması: Fizyoterapi Ve Rehabilitasyon Bölümü Örneği. Necmettin Erbakan Üniversitesi Sağllk Bilimleri Fakültesi Dergisi, 3(1), 15-20.

\section{Extended Abstract}

This paper investigated students' views and attitudes towards distance learning during the COVID-19 pandemic. The sample consisted of 276 students (168 women and $108 \mathrm{men}$ ) from the sociology department $(n=118)$ and physical education and sports vocational school (PESVS) $(n=158)$ of Ordu University. Participants were recruited by using purposive sampling. The study is limited to the views and attitudes of students from the sociology department and PESVS because the sociology department offers mostly theoretical courses, while PESVS offers mostly applied courses.

The study adopted a survey method, which is a quantitative research design. Data were collected online (Google Forms). The questionnaire consisted of 30 closed-ended and three open-ended questions. The data were analyzed using descriptive analysis.

The minimum sample size was calculated as 255. Therefore, the goal was to recruit as many participants as possible to reach the minimum sample size. Two hundred and eighty-eight students filled out the questionnaires. Twelve questionnaires were excluded due to various reasons. Therefore, the final sample consisted of 276 students (168 women and $108 \mathrm{men}$ ) from the sociology department $(n=118)$ and PESVS ( $n=158)$.

Participants were first-graders ( $n=68)$, second-graders, $(n=97)$, third-graders ( $n=55)$, or fourth-graders $(n=56)$. More than half the participants (65.2\%) had a moderate income. Ninety-six participants (34.8\%) lived in districts, $59.8 \%$ lived in apartments or gated communities. The parents of the majority of the participants (74.3\%) owned the apartments they lived in.

More than half the participants (64.1\%) had their own rooms. Only fourteen participants (5.4\%) stated that their parents did nothing to provide them with a quiet environment. One hundred and ten (39.9\%) participants stated that their parents supported them fully. The results show that most participants (85.5\%) are supported and provided with a quiet environment by their parents.

More than half the participants (59.1\%) did not have computers. More than half the participants (59.8\%) attended classes on their smartphones. Less than half the participants (40.2\%) used mobile Internet.

Forty-one participants (14.9\%) never missed classes, whereas $43.8 \%$ sometimes missed classes. The results show that more than half the participants (58.7\%) kept up with most of the classes. Less than half the participants (39.5\%) watched the classes again. One hundred and eighteen (43.1\%) participants made no time to study, suggesting a lack of motivation. More than half the participants spent time either on the Internet (37.7\%) or doing chores (31.2\%).

The majority of the participants (92\%) preferred face-to-face learning, mostly due to efficiency and productivity concerns ( $n=107)$, concentration problems ( $n=33)$, clarity $(n=30)$, and communication $(n=25)$. Twenty-two participants preferred distance learning because of the comforts of the home $(n=14)$, efficiency and productivity $(n=3)$, and access to online classes ( $n=2)$.

Participants considered distance learning to be of moderate quality (40.2\%) and either inefficient (32.9\%) or very inefficient (30.4\%). This result shows that more than half the students (55.8\%) do not feel like students. More than half the participants (61.2\%) disagreed with the possibility of distance learning becoming permanent. Therefore, we can state that students see school as an essential component of education despite advances in technology.

The majority of the participants (80.1\%) thought that distance learning adversely affected their performance, while more than half the participants (52.9\%) believed that distance learning did not affect their teachers' performance.

The participants' views of the advantages and disadvantages of distance learning are also reported by the participants. Their views on the advantages of distance learning were that it allowed them to attend classes from 
the comforts of their homes (31.5\%) and continue their education during the pandemic (17.4\%). A quarter of the participants (23.6\%) stated that distance learning had no disadvantages. According to those who preferred faceto-face learning, distance learning allowed them to attend classes from the comforts of their homes (32.3\%), continue their education during the pandemic (18.5\%), and watch classes again (11.4\%), and provided flexibility (5.5\%), affordability (3.5\%), and faster and more clear learning (2.4\%). Sixty-three participants who preferred face-to-face learning (24.8\%) stated that distance learning had no advantage. Twenty-two participants preferred distance learning because it provided flexibility $(n=6)$ and faster and more clear lectures $(n=3)$ and allowed them to watch classes again ( $n=5)$, attend classes from the comforts of their homes $(n=5)$, and continue their education during the pandemic $(n=1)$. Two of them stated no advantage.

According to participants, the disadvantages of distance learning were Internet issues (22.8\%), inefficiency (19.9\%), lack of discipline/too much comfort (11.2\%), and concentration problems (10.5\%). Participants who preferred face-to-face learning stated the disadvantages of distance learning as Internet issues (21.3\%), inefficiency (21.3\%), concentration problems (13\%), lack of discipline/too much comfort (11.4\%), and lack of an environment for discussion and communication (9.7\%). Participants who preferred face-to-face learning also stated that distance learning prevented them from understanding subjects (6.1\%), was not a good fit for applied courses (2.1\%), and caused asociality (4.3\%). Of those who preferred distance learning ( $n=22)$, nine (40.9\%) talked about Internet issues, while six (27.3\%) stated no disadvantages. Two participants talked about the lack of discussion and communication, while two others addressed the lack of discipline/too much comfort as the disadvantage of distance learning. 